\title{
The development of student teachers' views on pupil misbehaviour during an initial teacher training programme in England and Norway
}

\author{
Chris Kyriacou*, Elias Avramidis*, Harald Hpie**, Paul Stephens**, and Xge Hultgren** \\ *University of York, Department of Educational Studies, U.K. \\ **University of Stavanger, Faculty of Arts and Education, Norway.
}

\begin{abstract}
A group of postgraduate (secondary school) student teachers attending a teacher training course in York (England) and Stavanger (Norway) completed a questionnaire at the start $(\mathrm{N}=174)$ and at the end $(\mathrm{N}=128)$ of their course which explored their views regarding the factors accounting for pupil misbehaviour, the frequency of pupil misbehaviour, the strategies for dealing with pupil misbehaviour, and their confidence that as a full-time teacher they will have the skills needed to keep pupils engaged in their work and to deal with pupil misbehaviour that occurs. Overall, the major factor accounting for pupil misbehaviour was reported to be 'parents who do not instil proschool values in their children'; the most frequent pupil misbehaviour reported was 'talking out of turn (e.g. calling out, interrupting, inappropriate remarks or distracting chatter during the lesson)'; and the strategy rated most positively was 'establish clear and consistent school and classroom rules about the behaviours that are acceptable and that are unacceptable'. Both the York and Stavanger students grew in confidence over the year. The study also highlights areas where there appear to be shifts in students' views over the course of their training year and differences between the students across the two settings (York and Stavanger).
\end{abstract}




\section{INTRODUCTION}

There is little doubt that one of the major challenges facing student teachers is to develop an understanding of the nature and causes of pupil misbehaviour and to develop the classroom teaching skills that will enable them to minimise pupil misbehaviour occurring in the first place and to deal effectively with pupil misbehaviour when it does occur.

A number of studies have highlighted the particular concerns that student teachers have regarding how to deal with pupil misbehaviour (Avramidis et al., 2000; Hultgren \& Stephens, 1999; Kokkinos et al., 2004; Kyriacou \& Stephens, 1999), and indicate that such concerns is one of the main factors that discourages graduates from considering a career in teaching, and also causes trainee teachers to withdraw from a teacher training course or decide not to enter the profession at the end of the course (Hobson et al., 2006; Kokkinos et al., 2005).

In recent years, there has been a concern expressed in both England and Norway about the challenges facing new teachers in dealing with pupil misbehaviour and about how well student teachers are prepared during their initial teacher training courses to deal with pupil misbehaviour. The report in England of the House of Commons Education and Skills Committee (2004) identified the need for teacher training courses to develop trainees' skills to teach in challenging schools as an urgent priority, and the concerns raised there were taken up in a major government report on improving discipline in schools (Steer, 2005).

Similarly, in Norway, a former Minister of Education identified as a priority the need to help schools to deal more effectively with discipline problems (Clement, 2004). The 2003 PISA report (OECD, 2004) included data from OECD countries on 15 year old pupils' views of factors 
which hindered their learning to produce an 'index of disciplinary climate' based on how frequently pupils reported the following happens in every lesson or at least in most lessons: pupils don't listen to what the teachers says; there is noise and disorder; the teacher has to wait a long time for pupils to quieten down; pupils cannot work well; and pupils don't start working for a long time after the lesson begins. The OECD report identified disruptive behaviour as a major problem in Norwegian secondary schools. For example, 36 per cent of the Norwegian pupils reported that 'noise and disorder' happened in every lesson or at least in most lessons. The report cited Norway as one of three OECD countries with the greatest problems in this area (unfortunately, data for the U.K. on this index were not presented as the U.K. sample did not meet the PISA response rate standards for inclusion in the report).

As such, there is a need to gain a better understanding of how student teachers' views on pupil misbehaviour develop over the course of their initial teacher training programme. In particular, we need to know more about the extent to which the student teachers' views change in the direction of enabling them to become more confident and effective in dealing with pupil misbehaviour when they take up their first post as a qualified teacher.

The York-Stavanger research project on teacher education was established in 1998 with the aim of exploring teacher education in England and Norway by focussing on the views and experiences of student teachers at the Universities of York and Stavanger. The present study was developed as part of this on-going project to explore how student teachers' views on pupil misbehaviour develop over the course of their initial teacher training programme and whether the pattern of this development differed in the two settings of York and Stavanger. The study builds upon previous studies we have carried out which illustrated how teacher education programmes in the two countries differ in terms of the government's ideological view of the nature and role of 
teacher education (Stephens et al., 2004), how student teachers at York and Stavanger held differing expectations about what the job of being a teacher will be like (Kyriacou et al., 2003), and, more particularly, how student teachers at York and another Norwegian city, Kristiansand, have differing views regarding the nature of the unacceptability of certain pupil behaviours in the classroom (Stephens et al., 2005).

The present study explored one year full-time postgraduate ('PGCE' in England; 'PPU' in Norway) student teachers' views about pupil misbehaviour in the secondary school classroom. The study focuses on a cohort of student teachers training to teach in secondary schools in York and Stavanger. The key research questions were: (i) What views do these student teachers hold regarding pupil misbehaviour? (ii) Do these views change over the course of their training year? (iii) Are there any differences between the York and Stavanger cohorts?

\section{DATA COLLECTION}

The population for this study was the full cohort of one year full-time secondary school PGCE/PPU student teachers at the Universities of York and Stavanger. 131 PGCE students at York and 43 PPU students at Stavanger completed the questionnaire at the start of the course, and 95 PGCE students at York and 34 PPU students at Stavanger completed the questionnaire at the end of the course. The questionnaires were administered during a teaching session and were completed by all the students present at that session. The decrease in the number completing the second questionnaire was the result of some students leaving the course (19 at York, 6 at Stavanger) plus some absentees from the session at which the second questionnaire was administered. 
The questionnaire was designed to explore the student teachers' views concerning the causes and frequency of pupil misbehaviour, effective strategies to deal with it, and their confidence in being able to keep pupils engaged in their work and deal with misbehaviour. The design of the questionnaire took account of previous studies dealing with aspects of pupil misbehaviour (e.g. Bru et al., 2002; Kokkinos et al., 2004; Miller, 2003; Stephens et al., 2005) in order to enhance its reliability and validity. In addition, the questionnaire was piloted, and the Norwegian version was independently back translated into English.

A questionnaire approach was adopted in order to survey the field regarding the student teachers' perceptions. This may provide a useful base from which trends and issues identified here can be explored in more detail by interview.

The questionnaire comprised five key questions:

(i) How important do you think these factors are in accounting for secondary school pupils' misbehaviour in lessons? (14 items with a four-point response scale labelled: a major factor, a moderate factor, a mild factor, not a factor at all)

(ii) How frequently would you estimate the following forms of pupil misbehaviour occur in a typical lesson in secondary schools? (20 items with a five-point response scale labelled: almost every lesson, once or twice a day, once or twice a week, once or twice a month, less than once a month)

(iii) To what extent to do you think most pupil misbehaviour in secondary schools is best dealt with using the following strategies? (14 items with a four-point response scale labelled: definitely a good strategy, probably a good strategy, possibly a good strategy, not a good strategy) 
(iv) If you were to take up a post as a full-time teacher in a secondary school next year, how confident are you that you would have the skills needed to keep a typical class of pupils engaged in the work? (single item with a four-point response scale labelled: very confident, fairly confident, a bit confident, and not at all confident).

(v) If you were to take up a post as a full-time teacher in a secondary school next year, how confident are you that you would have the skills needed to deal swiftly and effectively with misbehaviour occurring in a typical class of pupils? (single item with a four-point response scale labelled: very confident, fairly confident, a bit confident, and not at all confident).

\section{RESULTS AND DISCUSSION}

The five tables shown give the percentage responses of the Stavanger and York students to each item at the start and at the end of their teacher training course. For ease of comparison, percentages are displayed here regarding only one point on the rating scale for tables 1 and 3, and for two points collapsed together for tables 2, 4 and 5. Care was taken to ensure that this form of presentation was not misleading in any way by checking these against tables showing all points on the rating scales.

Age and gender differences were also explored. However, given the limited sample size, it was felt that any trends suggested in these two respects were not sufficiently robust to warrant any detailed presentation and discussion here, but might indicate some leads for us to explore in future research. 


\section{Accounting for pupil misbehaviour}

Table I shows the responses to the following question: How important do you think these factors are in accounting for secondary school pupils' misbehaviour in lessons? There are six items which at least one-third of both the Stavanger and York students rated as a major factor at the start of the year. Starting with the highest percentage (averaged across the two groups), these were:

- Parents who do not instil pro-school values in their children;

- Teachers who do not project an authoritative presence;

- Teachers who are not skilful at dealing with misbehaviour swiftly;

- Teachers who are not skilful at keeping pupils engaged in the work;

- Pupils who have emotional and/or behavioural difficulties; and

- Teachers whom pupils find too lenient.

The six items with a high rating for both groups at the start of the year cover four classic areas: (i) parents who fail to support the school, (ii) skilful teaching which keeps pupils engaged in the work and curtails any misbehaviour quickly), (iii) an authoritative teacher presence, and (iv) challenging pupils. Although these six items still remain as the most important factors overall, in all six cases there was a decrease in the rating by the Stavanger students at the end of the year, which meant that by the end of the year, there was only one item that at least one-third of both the Stavanger and York students rated as a major factor. This was: 'teachers who do not project an authoritative presence'. 
Table I about here

The relatively high frequency for the item 'parents who do not instil pro-school values in their children' reported here is in line with a number of studies, such as the research conducted by Miller (2003) which looked at the views of teachers, pupils and parents in England regarding the causes of pupil misbehaviour.

There were no items that showed a marked change (either an increase or decrease of over $15 \%$ ) over the year for both the York and Stavanger students. However, there were a number of interesting differences between the two samples. More of the York group rated the following three items as a major factor more than did the Stavanger group (for a percentage difference greater than $15 \%$ ) for both the start-of-year and end-of-year data. These were:

- Parents who do not instil pro-school values in their children;

- Pupils who have emotional and/or behavioural difficulties; and

- It's a reaction to finding the work too difficult.

The Stavanger group rated no item as a major factor more than did the York group (for a percentage difference greater than $15 \%$ ). However there were two items where the difference in this direction for both the start-of-year and end-of-year data exceeded 5\%. These were 'teachers who do not project an authoritative presence' and 'the use of teaching methods that pupils find too passive'. It is interesting to note for the Stavanger group (compared with the York group) the higher rating of 'teachers who do not project an authoritative presence' as a major factor. Indeed, for the Stavanger group this factor also received the highest rating for both the start-of-year and end-of-year data 
(53.5\% and $52.9 \%$ respectively). This is perhaps not surprising against a backdrop of current government backing in Norway of anti-school bullying interventions in which the role of authoritative teachers is to the forefront (UFD, 2004; Olweus, 2001; Roland \& Sørensen Vaaland, 2003).

It is also pertinent to note that in his recent address to the (Norwegian) School Pupils' Parliament, the Minister of Education, Øystein Djupedal (2006), said:

"I want a school where pupils are taught to take social responsibility and to care for others. What we need are pupils who are critically aware! I regard this as one of the biggest challenges facing the Norwegian school."

We think that the Minister's 'subtext' is roughly as follows: Even though we want to hear your voice, respect your teachers and let them help you to behave properly. While some commentators might regard the politicians' concerns as indicative of the beginnings of a backlash against a prevailing humanitarian and democratic ethos that has traditionally characterised the classroom climate in Norwegian schools, the architects of prominent anti-school bullying programmes see their interventions as protecting the human rights of victims and of encouraging all pupils to behave prosocially (see, for example, Olweus, 2004). The point is not to compromise on liberal, egalitarian norms in school, but rather to allow teachers (and their pupils) to defend the values that underpin these norms more robustly.

Attribution theory had led us to expect that student teachers at the start of their training course (compared with at the end of their training course) would be more likely to identify factors to do 
with pupils (i.e. external to themselves) as the major factors accounting for pupil misbehaviour rather than factors to do with teachers (i.e. internal to themselves), but that as a result of their experiences during the training year, in which they would see ways in which their own skilful teaching can act to reduce pupil misbehaviour, we expected that by the end of the year factors to do with pupils would decrease and factors to do with teachers would increase. When we looked for any marked changes (defined as either an increase or decrease of over 15\%) over the year for both the York and Stavanger students, there was no clear support in these data for such a shift over the year away from a pupil-focused attribution towards a teacher-focused attribution.

However, when we compared the York and Stavanger students, it was noticeable that for the three most highly rated teacher-focused items overall (teachers who do not project an authoritative presence; teachers who are not skilful at dealing with misbehaviour swiftly; teachers who are not skilful at keeping pupils engaged in the work), in each case the rating by the York students increased over the year whilst the rating for the Stavanger group decreased over the year. When we then looked at the three most highly rated pupil-focused items overall (pupils who have emotional and/or behavioural difficulties; pupils who lack self-discipline; pupils who have a low self-esteem caused by low attainment), in each case the rating by both the York students and the Stavanger students decreased over the year.

This closer analysis offers some limited support to the view that for the York students there was some indication of a shift over the year away from a 'pathognomonic view' (i.e. locating the problem of pupil misbehaviour with pupils) towards an 'interventionist view' (locating the problem of pupil misbehaviour to the environment established by the teacher) (see Stanovich \& Jordan, 1998). For the Stavanger students, however, evidence of such a shift over the year is not apparent regarding these three teacher-focused items (which decreased rather than increased), although it is 
apparent in these three pupil-focused items. As we will see later, however, this difference between the two groups may in part be dependent on the degree to which their confidence increased over the year.

\section{The estimated frequency of pupil misbehaviour}

Table II shows the responses to the following question: How frequently would you estimate the following forms of pupil misbehaviour occur in a typical lesson in secondary schools? There are six items which at least two-thirds of both the Stavanger and York students rated as occurring either 'almost every lesson' or 'once or twice a day' for both the start-of-year and end-of-year data. Starting with the highest mean percentage, these were:

- Talking out of turn (e.g. calling out, interrupting, inappropriate remarks or distracting chatter during the lesson);

- Calculated work avoidance (e.g. delaying starting work, not having important books or equipment).

- Interrupting other pupils (e.g. by distracting them from work);

- Making unnecessary noise (e.g. by scrapping the chair, banging objects, or other noisy behaviour);

- General rowdiness, horseplay or mucking about; and

- Arriving late for the lesson.

Table II about here 
Interestingly, Ogden (1998) reported some comparative empirical data indicating that practising schoolteachers in England and Norway encounter the same kind of discipline problems that were reported here by the student teachers in our samples. Ogden compared the views of Norwegian secondary teachers with those reported by secondary school teachers in England and Wales nearly a decade earlier in the Elton Report (DES/WO, 1989). The most commonly reported problems in both national reports of teachers' experiences of pupil misbehaviour were: talking out of turn, calculated idleness or work avoidance, hindering other pupils, and not being punctual. Ogden noted that the frequency reported by the Norwegian teachers was lower than for the teachers in England and Wales. The high frequency for 'talking out of turn' reported in our study is also in line with a number of more recent studies, such as the findings of a survey reported by Infantino and Little (2005) which looked at the views of pupils at 12 secondary schools in Australia regarding pupil misbehaviour.

The York group rated no item as occurring either 'almost every lesson' or 'once or twice a day' more than did the Stavanger group (for a percentage difference greater than 15\%) for both the startof-year and end-of-year data. However, the Stavanger group rated one item as occurring either 'almost every lesson' or 'once or twice a day' more than did the York group (for a percentage difference greater than $15 \%$ ). This was for the item 'using a mobile phone during the lesson'.

There were only three items that showed a marked change (either an increase or decrease of over $15 \%)$ over the year for both the York and Stavanger students. These were a decrease in 'general rowdiness, horseplay or mucking about', 'cheeky or rude remarks or replies to the teacher' and 'using mobile phone during the lesson'.

As noted earlier, in Norway, the problem of bullying in schools has received a great deal of attention, and a whole school approach to tackling antisocial and aggressive behaviour is emphasised 
in two national, anti-school bullying interventions, the Olweus Programme and Project Zero, both of which receive government funding (Stephens, 2006). In addition, in England, anti-bullying interventions have been prioritised in the national strategy for school improvement for secondary schools (Secondary National Strategy, 2006). It is thus interesting to note that many of the student teachers (46.6\% of the Stavanger group and $25.2 \%$ of the York group) estimated that bullying occurs 'almost every lesson' or 'once or twice a day' in the start-of-year data, but that these figures fell for both groups by the end of the year. This may suggest that quite a lot of the students in both groups were aware of bullying as a major issue when beginning their training course, but that they may have overestimated its prevalence in lessons.

\section{Strategies for dealing with pupil misbehaviour}

Table III shows the responses to the following question: To what extent to do you think most pupil misbehaviour in secondary schools is best dealt with using the following strategies? There are three strategies which at least one-third of both the Stavanger and York students rated as definitely a good strategy for both the start-of-year and end-of-year data. Starting with the highest mean percentages, these were:

- Establishing clear and consistent school and classroom rules about the behaviours that are acceptable and are unacceptable;

- Speak to the pupil in a firm and assertive manner; and

- Make sure all pupils are given work to do as soon as possible that will keep them occupied. 
Table III about here

It is interesting to note the high frequency for the item 'establishing clear and consistent school and classroom rules about the behaviours that are acceptable and are unacceptable' as this strategy is featured highly in the government-funded resource packs produced for secondary school teacher education tutors in England aimed to enhance the student teachers' skills development in the area of dealing with pupil misbehaviour (e.g. Behaviour4Learning, 2006) and is also in line with the findings of a number of recent research studies (see Evertson \& Weinstein, 2006).

There were, in addition, three strategies for which there was an increase of over $15 \%$ in their rating as definitely a good strategy for both the Stavanger and York students over the year. These were:

- Make sure all pupils are given work to do as soon as possible that will keep them occupied;

- Try to get the pupil re-engaged in doing their school work with as little fuss as possible; and

- Investigate the misbehaviour in a sympathetic and non-threatening manner.

Conversely, there were no strategies that showed a similar decrease (viz. over 15\%) over the year.

There were a number of interesting differences between the two samples. More of the York group rated the following five items as 'definitely a good strategy' than did the Stavanger group (for a percentage difference greater than 15\%) for both the start of year and end of year data. These were:

- Establish clear and consistent school and classroom rules about the behaviours that are acceptable and that are unacceptable; 
- Try to get the pupil re-engaged in doing their schoolwork with as little fuss as possible;

- Use your authoritative presence to guide pupil towards re-engaging in the work;

- Investigate the misbehaviour in a sympathetic and non-threatening manner; and

- Threaten to punish the pupil (e.g. with a detention) if the misbehaviour persists.

The massive difference in the endorsement of the strategy 'try to get the pupil re-engaged in doing their schoolwork with as little fuss as possible' between the York group (70.0\%) and the Stavanger group $(17.1 \%)$ at the start of the year is striking, and this difference remains large at the end of the year $(85.9 \%$ and $40.6 \%$ respectively). This suggests a major difference in philosophy between these two groups of students at both the start and at the end of their training course. One can describe the Stavanger group as favouring 'the use of clear and consistent rules' coupled with 'a firm and assertive manner', and the York group as favouring 'the use of clear and consistent rules' coupled with 're-engaging pupils in their schoolwork with little fuss'.

\section{Confidence}

Table IV shows the responses to the following question: If you were to take up a post as a full-time teacher in a secondary school next year, how confident are you that you would have the skills needed to keep a typical class of pupils engaged in the work? The majority of students in both the Stavanger and York groups rated themselves as either 'very confident' or 'fairly confident' regarding their skills for engaging pupils in work. These figures showed an increase over the year for both groups.

Table IV about here 
Table V shows the responses to the following question: If you were to take up a post as a fulltime teacher in a secondary school next year, how confident are you that you would have the skills needed to deal swiftly and effectively with misbehaviour occurring in a typical class of pupils? Whilst the majority of students in the Stavanger group rated themselves as either 'very confident' or 'fairly confident' regarding their skills for dealing with misbehaviour at the start-of the year, only a minority of students in the York group. These figures showed an increase over the year for both groups.

Table V about here

These findings are in line with a number of studies which have indicated that student teachers' confidence in their teaching skills grows during their training year and that, by the end of the year, a large majority of students feels confident about this (e.g. Hobson et al., 2006).

Looking at tables IV and V together, it is evident that the students' confidence in their skills to keep pupils engaged is higher than for their skills in dealing with misbehaviour. In addition, the confidence of the York group started at a lower base than for the Stavanger group but finished higher. Questionnaire data for the York sample additionally asked for the student's date of birth as well as their curriculum area. This enabled the end-of-year questionnaire to be matched with each student's start-of-year questionnaire. A matched-paired t-test performed for the York data for 94 students who completed both questionnaires indicated that an increase in confidence in these two sets of skills was statistically significant (for $\mathrm{P}<0.001$ ). ). It is worth noting here that the statistically significant differences detected by the paired-samples t-test might be in part due to the analysis not 
including those students who left the course; these students would be likely to have reported low confidence had they taken part in the second (end-of-year) administration.

As noted earlier, the much greater rise in the confidence level for the York students compared with the Stavanger students may in part explain why there was some evidence of a shift for the York students over the year away from holding a pathognomonic view towards holding an interventionist view regarding the factors accounting for pupil misbehaviour. But this was not evident for the Stavanger students, perhaps because the degree to which confidence increases may go hand in hand with the students' appreciation of how their own skilful behaviour as teachers can impact favourably on minimising pupil misbehaviour. The idea that a shift over the year in student teachers' attributions regarding the factors accounting for pupil misbehaviour is in part dependent on a shift in their confidence in managing classroom behaviour, is in line with the argument developed by Miller (2003), who makes an important distinction between, on the one hand, the actors to whom pupil misbehaviour is attributed (viz. pupils, teachers, and parents) and, on the other hand, the degree to which those actors are perceived to have control over the pupil misbehaviour. The greater the perceived control, the greater the strength of attribution. If, over the training year, teachers' confidence is a reflection of their sense of being able to control classroom behaviour better, then according to Miller's viewpoint, they would increasingly attribute any failure to control pupil behaviour to teachers' lack of classroom management skills.

\section{CONCLUSION}

These data shed some interesting light on student teachers' views about the causes of pupil misbehaviour, their frequency and the strategies to deal with it. The study also highlights areas 
where there appear to be shifts in students' views over the course of their training year and also highlights differences between the students across the two settings (York and Stavanger). Our findings indicate that both groups grew in confidence over the year and that their view of the usefulness of certain strategies also increased over the year (most notably for 'try to get the pupil reengaged in doing their schoolwork with as little fuss as possible').

There was no marked rise in both groups of students' views about the major factors that account for pupil misbehaviour. This suggests that their experiences during the training course did not lead to a marked shift in attributing blame to one or more particular factors. Nevertheless, there was some limited evidence of a shift for the York students over the year away from holding a pathognomonic view towards holding an interventionist view regarding the factors accounting for pupil misbehaviour.

There was no marked rise in both groups of students' estimated frequency of pupil misbehaviour over the year. This suggests that their experiences during the training course did not result in a marked upward shift in the frequency of pupil misbehaviour that they estimated at the start of the year would occur in schools. Indeed, the data here suggest that some downward shifts between the start-of-year and end-of-year estimates were evident. This may in part be attributable to the often exaggerated reports in UK and Norwegian media about rising pupil misbehaviour. This may have resulted in students starting their training with a heightened expectation about the prevalence of pupil misbehaviour which is gradually dispelled by their experiences during the year.

Our findings suggest that it would be useful to explore whether particular experiences on campus and at school either confirm or modify student teachers' initial views on pupil misbehaviour. Interviews and focus-group methods could usefully be employed to explore in details if, how and why the student teachers experiential encounters with the programmes at York and Stavanger impact 
on the student teachers' views and the influenced played by the programme content and policy context regarding initial teacher training that exists in the two countries (Stephens et al., 2004). 


\section{REFERENCES}

AVRAMIDIS, E., BAYLISS, P. \& BURDEN, R. (2000) Student teachers' attitudes towards the inclusion of children with special educational needs in the ordinary school, Teaching and Teacher Education, 16(3), pp. 277-293.

BEHAVIOUR4LEARNING (2006) Behaviour and Attendance Materials for Secondary School Initial Teacher Training Tutors. (Northampton, The Initial Teacher Training Professional Resource Network (IPRN) for Behaviour, School of Education, University of Northampton).

BRU, E., STEPHENS, P. \& TORSHEIM, T. (2002) Students' perceptions of class management and reports of their own misbehaviour, Journal of School Psychology, 40(4), pp. 287-307.

CLEMENT, K. (2004) Norwegian schools are in need of a 'knowledge uplift'. Press release no. 08104, 6th December 2004, Ministry of Education, Oslo, Norway.

DEPARTMENT OF EDUCATION AND SCIENCE AND THE WELSH OFFICE (DES/WO) (1989). Discipline in Schools (the Elton Report) (London, HMSO).

DJUPEDAL, Ø. (2006) Tale til Elevtinget 2006 [Speech to School Pupils' Parliament $14^{\text {th }}$ March 2006; in Norwegian]. Ministry of Education, Oslo. Downloaded on $27^{\text {th }}$ July 2006 from: http://odin.dep.no/kd/norsk/bn.html 
EVERTSON, C. M. \& WEINSTEIN, C. S.. (eds) (2006) Handbook of Classroom Management: Research, Practice and Contemporary Issues (New York, Lawrence Erlbaum).

HOBSON, A. J., MALDEREZ, A., TRACEY, L., GIANNAKAKI, M. S., PELL, R. G., KERR, K., CHAMBERS, G. N., TOMLINSON, P. D. \& ROPER, T. (2006). Becoming a Teacher: Student Teachers' Experiences of Initial Teacher Training in England (Research Report RR744) (London: DfES).

\section{HOUSE OF COMMONS EDUCATION AND SKILLS COMMITTEE (2004) Secondary}

Education: Teacher Retention and Recruitment (fifth report of the session 2003-04) volume 1: Report together with formal minutes (London, Stationery Office).

HULTGREN, X \& STEPHENS, P. (1999) Class management in senior high schools during teaching practice: the Norwegian experience, Mentoring and Tutoring, 6(3), pp. 18-30.

INFANTINO, J. \& LITTLE, E. (2005) Students' perceptions of classroom behaviour problems and the effectiveness of different disciplinary methods, Educational Psychology, 25(5), pp. 491-508.

KOKKINOS, C. M., PANAYIOTOU, G. \& DAVAZOGLOU, A. M. (2004) Perceived seriousness of pupils' undesirable behaviours: the student teachers' perspective, Educational Psychology, 24(1), pp. 109-120. 
KOKKINOS, C. M., PANAYIOTOU, G. \& DAVAZOGLOU, A. M. (2005) Correlates of teacher appraisals of student behaviours, Psychology in the Schools, 42(1), pp. 79-89. 
KYRIACOU, C., KUNC, R., STEPHENS, P. \& HULTGREN, X. (2003) Student teachers' expectations of teaching as a career in England and Norway, Educational Review, 55(3), pp. 255-263.

KYRIACOU, C. \& STEPHENS, P. (1999) Student teachers' concerns on teaching practice, Evaluation and Research in Education, 13(1), pp. 18-31.

MILlER, A. (2003) Teachers, Parents and Classroom Behaviour: A Psychosocial Approach (Maidenhead, Open University Press).

OECD (2004) Learning for Tomorrow's World: First Results from PISA 2003 (Paris, OECD).

OGDEN, T. (1998) Elevatferd og laeringsmiljø [Pupil behaviour and learning climate; in Norwegian] (Oslo, Norway, KUF).

OLWEUS, D. (2001) Olweus' Kjerneprogram mot Mobbing og Antisosial Atferd: En Larerveiledning [Olweus's Core Programme against Bullying and Antisocial Behaviour: A Teacher Handbook; in Norwegian] Version III (Bergen, University of Bergen).

OLWEUS, D. (2004) Mobbing i skolen [Bullying at School; in Norwegian] (Oslo, Gyldendal Akademisk). 
ROLAND, E. \& SØRENSEN VAALAND, G. (2003) Zero, SAFs program mot mobbing: Larerveiledning [Zero, SAF's anti-bullying programme: Teacher Guide; in Norwegian]. $2^{\text {nd }}$ edition (Centre for Behavioural Research, Stavanger University College, Norway).

SECONDARY NATIONAL STRATEGY (2006) Secondary National Strategy for School Improvement: Summer Term Bulletin, June 2006 (London, Department for Education and Skills).

STANOVICH, P. J. \& JORDAN, A. (1998) Canadian teachers' and principals' beliefs about inclusive education as predictors of effective teaching in heterogeneous classroom, Elementary School Journal, 98(3), pp. 221-238.

STEER, A. (chair) (2005) Learning Behaviour: The Report of the Practitioners' Group on School Behaviour and Discipline (the Steer Report) (London, Department for Education and Skills).

STEPHENS, P. (2006) The big idea in Norwegian anti-bullying interventions. Paper presented at the International Seminar held at the University of York, Department of Educational Studies, $16^{\text {th }}$ June.

STEPHENS, P., KYRIACOU, C. \& TØNNESSEN, F-E. (2005) Student teachers' views of pupil misbehaviour in classrooms: a Norwegian and an English setting compared, Scandinavian Journal of Educational Research, 49(2), pp. 203-216. 
STEPHENS, P., TØNNESSEN, F-E. \& KYRIACOU, C. (2004) Teacher training and teacher education in England and Norway: a comparative study of policy goals, Comparative Education, 40(1), pp. 109-130.

\section{UTDANNINGS- OG FORSKNINGSDEPARTEMENTET (UFD) (Norwegian}

Ministry of Education) (2004) The Manifesto Against Bullying: Plan of Action for 2004 (Oslo, Norwegian Ministry of Education).

\section{Table I}

The percentage of student teachers who rated these factors as 'a major factor' in response to the question: "How important do you think these factors are in accounting for secondary school pupils' misbehaviour in lessons?" (in descending order of the mean)

\begin{tabular}{|l|c|c|c|c|c|}
\hline & $\begin{array}{c}\text { Stavanger } \\
\text { (start of } \\
\text { year) }\end{array}$ & $\begin{array}{c}\text { Stavanger } \\
\text { (end of } \\
\text { year) }\end{array}$ & $\begin{array}{c}\text { York } \\
\text { (start of } \\
\text { year) }\end{array}$ & $\begin{array}{c}\text { York } \\
\text { (end of } \\
\text { year) }\end{array}$ & Mean \\
\hline $\begin{array}{l}\text { Parents who do not instil pro-school values in their } \\
\text { children }\end{array}$ & 41.9 & 32.4 & 57.3 & 62.8 & 48.6 \\
\hline $\begin{array}{l}\text { Teachers who do not project an authoritative } \\
\text { presence }\end{array}$ & 53.5 & 52.9 & 39.7 & 43.6 & 47.4 \\
\hline Teachers who are not skilful at dealing with & 48.8 & 29.4 & 50.4 & 59.6 & 47.1 \\
\hline
\end{tabular}




\begin{tabular}{|c|c|c|c|c|c|}
\hline misbehaviour swiftly & & & & & \\
\hline $\begin{array}{l}\text { Teachers who are not skilful at keeping pupils } \\
\text { engaged in the work }\end{array}$ & 45.2 & 30.3 & 53.4 & 55.3 & 46.1 \\
\hline $\begin{array}{l}\text { Pupils who have emotional and/or behavioural } \\
\text { difficulties }\end{array}$ & 37.2 & 20.6 & 53.9 & 39.4 & 37.8 \\
\hline Teachers whom pupils find too lenient & 34.9 & 29.4 & 38.9 & 36.2 & 34.9 \\
\hline Pupils who lack self-discipline & 27.9 & 23.5 & 35.4 & 22.6 & 27.4 \\
\hline $\begin{array}{l}\text { Pupils who have a low self-esteem caused by low } \\
\text { attainment }\end{array}$ & 26.2 & 14.7 & 39.7 & 25.0 & 26.4 \\
\hline $\begin{array}{l}\text { The use of teaching methods that pupils find too } \\
\text { passive }\end{array}$ & 25.6 & 26.5 & 19.8 & 12.8 & 21.2 \\
\hline $\begin{array}{l}\text { The school curriculum is not interesting or relevant } \\
\text { enough }\end{array}$ & 11.9 & 11.8 & 18.6 & 20.7 & 15.8 \\
\hline Pupils who get bored from time to time & 9.3 & 14.7 & 19.8 & 10.6 & 13.6 \\
\hline It's a reaction to finding the work too difficult & 7.0 & 0 & 22.3 & 19.1 & 12.1 \\
\hline $\begin{array}{l}\text { It's natural for adolescents to want to rebel from time } \\
\text { to time }\end{array}$ & 7.1 & 5.9 & 9.9 & 12.9 & 9.0 \\
\hline Teachers whom pupils find too harsh & 2.4 & 0 & 5.4 & 4.3 & 3.0 \\
\hline
\end{tabular}

\section{Table II}

The percentage of student teachers who estimated these forms of pupil misbehaviour as occurring either 'almost every lesson' or 'once or twice a day' in response to the question: "How frequently would you estimate the following forms of pupil misbehaviour occur in a typical lesson in secondary schools?" (in descending order of the mean)

\begin{tabular}{|c|c|c|c|c|c|}
\hline & $\begin{array}{c}\text { Stavanger } \\
\text { (start of } \\
\text { year) }\end{array}$ & $\begin{array}{c}\text { Stavanger } \\
\text { (end of } \\
\text { year) }\end{array}$ & $\begin{array}{c}\text { York } \\
\text { (start of } \\
\text { year) }\end{array}$ & $\begin{array}{c}\text { York } \\
\text { (end of } \\
\text { year) }\end{array}$ & Mean \\
\hline $\begin{array}{l}\text { Talking out of turn (e.g. calling out, interrupting, inappropriate } \\
\text { remarks or distracting chatter during the lesson) }\end{array}$ & 95.2 & 88.2 & 95.4 & 91.3 & 92.5 \\
\hline $\begin{array}{l}\text { Calculated work avoidance (e.g. delaying starting work, not } \\
\text { having important books or equipment) }\end{array}$ & 86.0 & 88.2 & 93.9 & 89.3 & 89.4 \\
\hline Interrupting other pupils (e.g. by distracting them from work) & 81.4 & 76.4 & 93.1 & 83.7 & 83.7 \\
\hline $\begin{array}{l}\text { Making unnecessary noise (e.g. by scraping the chair, banging } \\
\text { objects, or other noisy behaviour) }\end{array}$ & 88.3 & 70.6 & 88.5 & 86.9 & 83.6 \\
\hline General rowdiness, horseplay or mucking about & 88.1 & 68.8 & 90.8 & 75.3 & 80.8 \\
\hline
\end{tabular}




\begin{tabular}{|c|c|c|c|c|c|}
\hline Arriving late for the lesson & 76.7 & 73.5 & 77.9 & 79.3 & 76.9 \\
\hline $\begin{array}{l}\text { Getting out of seat (or workplace) without permission (if this is } \\
\text { normally required) }\end{array}$ & 60.4 & 69.7 & 74.8 & 57.0 & 65.5 \\
\hline Resting head on desk during the lesson & 78.6 & 70.6 & 70.2 & 38.5 & 64.5 \\
\hline Cheeky or rude remarks or replies to the teacher & 69.8 & 52.9 & 73.3 & 51.6 & 61.9 \\
\hline $\begin{array}{l}\text { Verbal abuse towards other pupils (e.g. wounding or insulting } \\
\text { remarks) }\end{array}$ & 67.5 & 53.0 & 60.3 & 47.3 & 57.0 \\
\hline Persistent breaking of class or school rules & 23.8 & 44.1 & 50.4 & 55.4 & 43.4 \\
\hline Using a mobile phone during the lesson & 55.8 & 35.3 & 28.2 & 7.6 & 31.7 \\
\hline Bullying other pupils & 46.6 & 20.6 & 25.2 & 16.3 & 27.2 \\
\hline $\begin{array}{l}\text { Physical aggression towards other pupils (e.g. by pushing or } \\
\text { striking) }\end{array}$ & 18.6 & 14.7 & 13.0 & 9.7 & 14.0 \\
\hline Racist remarks & 9.3 & 5.9 & 2.4 & 4.4 & 5.5 \\
\hline $\begin{array}{l}\text { Vandalism (e.g. breaking or damaging furniture or things } \\
\text { belonging to other pupils, the teacher or the school) }\end{array}$ & 0 & 5.9 & 6.1 & 4.3 & 4.1 \\
\hline Hostile argument with the teacher & 0 & 10.8 & 0 & 5.4 & 4.1 \\
\hline Physical aggression towards the teacher & 0 & 0 & 0 & 3.3 & 0.8 \\
\hline $\begin{array}{l}\text { Under the influence of substance abuse (e.g. alcohol or drugs) } \\
\text { upon entering the classroom }\end{array}$ & 0 & 0 & 0.8 & 2.2 & 0.8 \\
\hline $\begin{array}{l}\text { Bringing a striking or stabbing weapon into the classroom (e.g. a } \\
\text { club or a knife) }\end{array}$ & 0 & 0 & 0 & 2.2 & 0.6 \\
\hline
\end{tabular}

\section{Table III}

The percentage of student teachers who rated these strategies as 'definitely a good strategy' in response to the question: "To what extent to do you think most pupil misbehaviour in secondary schools is best dealt with using the following strategies?" (in descending order of the mean)

\begin{tabular}{|c|c|c|c|c|c|}
\hline & $\begin{array}{l}\text { Stavanger } \\
\text { (start of } \\
\text { year) }\end{array}$ & $\begin{array}{l}\text { Stavanger } \\
\text { (end of } \\
\text { year) }\end{array}$ & $\begin{array}{l}\text { York } \\
\text { (start of } \\
\text { year) }\end{array}$ & $\begin{array}{l}\text { York } \\
\text { (end of } \\
\text { year) }\end{array}$ & Mean \\
\hline $\begin{array}{l}\text { Establish clear and consistent school and classroom rules about } \\
\text { the behaviours that are acceptable and that are unacceptable }\end{array}$ & 66.7 & 71.9 & 92.4 & 96.7 & 81.9 \\
\hline Speak to the pupil in a firm and assertive manner & 71.4 & 68.8 & 51.1 & 64.1 & 63.9 \\
\hline $\begin{array}{l}\text { Make sure all pupils are given work to do as soon as possible } \\
\text { that will keep them occupied }\end{array}$ & 42.9 & 62.5 & 44.2 & 77.2 & 56.7 \\
\hline $\begin{array}{l}\text { Try to get the pupil re-engaged in doing their schoolwork with } \\
\text { as little fuss as possible }\end{array}$ & 17.1 & 40.6 & 70.0 & 85.9 & 53.4 \\
\hline $\begin{array}{l}\text { Have a conversation with the pupil after the lesson in which } \\
\text { you try to counsel the pupil towards understanding why doing } \\
\text { the work and not misbehaving is in their best interests }\end{array}$ & 32.5 & 43.8 & 56.5 & 53.3 & 46.5 \\
\hline $\begin{array}{l}\text { Use your authoritative presence to guide pupil towards re- } \\
\text { engaging in the work }\end{array}$ & 24.4 & 37.5 & 41.4 & 55.4 & 39.7 \\
\hline
\end{tabular}




\begin{tabular}{|c|c|c|c|c|c|}
\hline $\begin{array}{l}\text { Investigate the misbehaviour in a sympathetic and non- } \\
\text { threatening manner }\end{array}$ & 7.5 & 22.6 & 32.3 & 55.4 & 29.5 \\
\hline $\begin{array}{l}\text { Issue a quiet reprimand about the misbehaviour that other } \\
\text { pupils do not overhear }\end{array}$ & 14.3 & 22.6 & 19.2 & 33.7 & 22.5 \\
\hline $\begin{array}{l}\text { Have a conversation with the pupil after the lesson in which } \\
\text { you issue a firm warning to the pupil not to misbehave again }\end{array}$ & 12.2 & 12.5 & 23.7 & 27.5 & 19.0 \\
\hline Issue the pupil with a sanction (e.g. a detention) & 11.9 & 9.4 & 13.7 & 17.4 & 13.1 \\
\hline $\begin{array}{l}\text { Threaten to punish the pupil (e.g. with a detention) if the } \\
\text { misbehaviour persists }\end{array}$ & 2.4 & 6.3 & 18.5 & 22.0 & 12.3 \\
\hline $\begin{array}{l}\text { Threaten to involve a more senior member of staff if the } \\
\text { misbehaviour persists }\end{array}$ & 0 & 3.1 & 14.6 & 18.5 & 9.1 \\
\hline Give pupils easier work to ensure that they are kept occupied & 11.9 & 12.5 & 2.3 & 3.3 & 7.5 \\
\hline $\begin{array}{l}\text { Issue a loud and public reprimand to the pupil about the } \\
\text { misbehaviour }\end{array}$ & 2.4 & 3.2 & 4.6 & 1.1 & 2.8 \\
\hline
\end{tabular}

\section{Table IV}

The percentage of student teachers who rated themselves as either 'very confident' or 'fairly confident' in response to the question: "If you were to take up a post as a full-time teacher in a secondary school next year, how confident are you that you would have the skills needed to keep a typical class of pupils engaged in the work?"

\begin{tabular}{|c|c|c|c|}
\hline $\begin{array}{c}\text { Stavanger } \\
\text { (start of year) }\end{array}$ & $\begin{array}{c}\text { Stavanger } \\
\text { (end of year) }\end{array}$ & $\begin{array}{c}\text { York } \\
\text { (start of year) }\end{array}$ & $\begin{array}{c}\text { York } \\
\text { (end of year) }\end{array}$ \\
\hline 73.2 & 81.2 & 58.4 & 92.4 \\
\hline
\end{tabular}

\section{Table V}

The percentage of student teachers who rated themselves as either 'very confident' or fairly confident' in response to the question: "If you were to take up a post as a full-time teacher in a secondary school next year, how confident are you that you would have the skills needed to deal swiftly and effectively with misbehaviour occurring in a typical class of pupils?"

\begin{tabular}{|c|c|c|c|}
\hline $\begin{array}{c}\text { Stavanger } \\
\text { (start of year) }\end{array}$ & $\begin{array}{c}\text { Stavanger } \\
\text { (end of year) }\end{array}$ & $\begin{array}{c}\text { York } \\
\text { (start of year) }\end{array}$ & $\begin{array}{c}\text { York } \\
\text { (end of year) }\end{array}$ \\
\hline 58.9 & 65.6 & 36.9 & 87.0 \\
\hline
\end{tabular}

